\title{
Immunoprofiling of leukemic stem cells CD34+/CD38-/CD123+ delineate FLT3/ITD-positive clones
}

Adhra Al-Mawali ${ }^{1,2^{*}}$, David Gillis ${ }^{1}$ and lan Lewis $^{1}$

\begin{abstract}
Background: Acute myeloid leukemia (AML) is a heterogeneous clonal disorder presenting with accumulation of proliferating undifferentiated blasts. Xenograft transplantation studies have demonstrated a rare population of leukemia-initiating cells called leukemic stem cells (LSCS) capable of propagating leukemia that are enriched in the CD34+/CD38- fraction. LSCs are quiescent, resistant to chemotherapy and likely responsible for relapse and therefore represent an ideal target for effective therapy. LSCS are reported to overexpress the alpha subunit of the IL-3 receptor (CD123) compared to normal CD34+/CD38- hematopoietic stem cells. It has not been demonstrated whether CD123-positive (CD34+/CD38-) subpopulation is enriched for any clonal markers of AML or any LSC properties. The aims of this study were to investigate whether FMS-like tyrosine kinase (FLT3)/internal tandem duplication (ITD) mutations are present at LSC level and whether FLT3/ITD mutation is confined to LSC as defined by CD34+/CD38-/CD123+ and not CD34+/CD38-/CD123-.

Methods: Thirty-four AML cases were analyzed by five-color flow cytometry and sequential gating strategy to characterize of CD34+/CD38-/CD123+ cells. These cells were sorted, analyzed by PCR, and sequenced for FLT3/ITD.

Results: In this study, we confirm significant expression of CD123 in 32/34 cases in the total blast population (median expression $=86 \%$ ). CD123 was also expressed in the CD34+/CD38- cells ( $96 \pm 2 \%$ positive) from 28/32 for CD123+ AML. CD123 was not expressed/low in normal bone marrow CD34+/CD38- cells (median expression $=0 \%$, range $(0-.004 \%)$. AML samples were tested for FLT3/ITD (10 positive/25). FLT3/ITD+ AML cases were sorted into two putative LSC populations according to the expression of CD123 and analyzed for FLT3/ITD again in the stem cell fractions CD34+/CD38-/CD123+ and CD34+/CD38-/CD123-. Interestingly, FLT3/ITD was only detected in CD34+/CD38-/CD123+ (7/7) and not in CD34+/CD38-/CD123- subpopulation (6/7).
\end{abstract}

Conclusions: This finding shows that FLT3/TD are present at LSC level and may be a primary and not secondary event in leukemogenesis, and the oncogenic events of FLT3/ITD happen at a cell stage possessing CD123. It shows that CD123 immunoprofiling provides further delineation of FLT3+ LSC clone. This novel finding provides a rationale for treatment involving CD123-targeting antibodies with intracellular FLT3 inhibitors directed against CD34+/CD38-/CD123+. This may result in more effective anti-LSC eradication.

Keywords: Acute myeloid leukemia, FLT3/ITD, Leukemic stem cells, CD34+/CD38-/CD123+, Flow cytometry

\footnotetext{
* Correspondence: adhra.almawali@gmail.com; adhra.almawali@imvs.sa.gov.au

'Division of Human Immunology and Haematology, SA Pathology, Hanson Institute, Frome Road, Adelaide, SA 5000, Australia

${ }^{2}$ Centre of Studies and Research, Ministry of Health, Muscat, Sultanate of Oman
} 


\section{Background}

Acute myeloid leukemia (AML) represents a group of clonal hematopoietic stem cell disorders in which both failure to differentiate and increased proliferation potential in the stem cell compartment result in accumulation of non-functional cells termed myeloblasts. While the majority of patients with AML achieve a complete remission (CR) with induction therapy, more than half of these subsequently relapse and eventually die of the disease [1]. Relapse is thought to occur because of the failure of chemotherapy to eradicate non-proliferating but selfrenewing leukemia stem cells [2]. Human AML stem cells, the so-called leukemic stem cells (LSCs), have been defined as CD34+/CD38- cells with severe combined immunodeficient (SCID) mouse-repopulating ability, which is a reflection of their capacity to self-renew $[3,4]$.

Previous studies suggest that LSCs are biologically distinct from more mature leukemic blasts and may not be responsive to conventional chemotherapeutic regimens [5-7]. One potential difference between normal and leukemic cells lies in their response to hematopoietic growth factors. It could be speculated that differential sensitivity to cytokines may also exist at the stem cell level [8]. A potential unique marker of LSCs is interleukin-3 receptor alpha chain (CD123) which has been shown to be highly expressed on leukemic but not normal CD34+/CD38hematopoietic cells, with a negative impact on the outcome and prognosis in AML patients [8-10] (Table 1).

FMS-like tyrosine kinase (FLT3), which belongs to a group of class III receptor tyrosine kinases, is preferentially expressed on hematopoietic stem/progenitor cells and plays a role in both differentiation and proliferation $[11,12]$. FLT3 is also expressed on the leukemic blasts in the majority of cases of acute leukemia, even in CD34negative cases [13-15]. Internal tandem duplications (ITDs) of varying length in the juxta-membrane (JM) region occur due to constitutive activation of the FLT3 receptor and are correlated with poor prognosis in AML patients [16-18].

The aim of this study was to investigate whether or not FLT3/ITD mutations are present at LSC level. We explore whether or not FLT3/ITD mutation is confined to the population of LSC as defined by CD34+/CD38-/CD123+.

Therefore, we explored the issue of whether or not FLT3/ ITD mutations are present at LSC level as defined by the phenotype CD34+/CD38-/CD123+. Seven primary AML samples harboring FLT3/ITD mutations were sorted into stem cell-enriched fractions CD34+/CD38-/CD123+ and stem cell-enriched fractions lacking CD123, and FLT3/ITD were then analyzed in the two-sorted fractions. Our data provide the first definitive evidence that FLT3/ITD mutations occur at LSC level at a stage of cells that possess interleukin3 (IL-3) $\alpha$ receptor (CD123). It is speculated that FLT3/ITD mutation could make the LSCs more capable of expanding in the environment and development of leukemia [19].
Table 1 Clinical characteristics of AML patients according to FLT3/ITD status

\begin{tabular}{|c|c|c|}
\hline Patient characteristics & $\begin{array}{l}\text { AML pos for } \\
\text { FLT3/ITD }\end{array}$ & $\begin{array}{l}\text { AML neg for } \\
\text { FLT3/ITD }\end{array}$ \\
\hline No. of patients & 12 & 27 \\
\hline Male/female & $8 / 4$ & $17 / 10$ \\
\hline Age at diagnosis, median, (range) & $62(23-73)$ & $69(23-88)$ \\
\hline $\begin{array}{l}\text { WBC count at diagnosis } \times 10^{9} / \mathrm{L} \text {, } \\
\text { median (range) }\end{array}$ & $6.6(0.9-179)$ & $6.3(0.7-227)$ \\
\hline $\begin{array}{l}\text { BM blasts \% by morphology, } \\
\text { median (range) }\end{array}$ & $72(26-85)$ & $35(20-87)$ \\
\hline AML de novo/secondary $n(\%)$ & $9(75) / 3(25)$ & $23(85) / 4(15)$ \\
\hline \multicolumn{3}{|l|}{ FAB classification, $n(\%)$} \\
\hline Mo & $0(0)$ & $0(0)$ \\
\hline M1 & $6(50)$ & $2(7)$ \\
\hline $\mathrm{M} 2$ & $1(8)$ & $10(37)$ \\
\hline M3 & $2(17)$ & $2(7)$ \\
\hline M4 & $1(8)$ & $3(11)$ \\
\hline M5 & $1(8)$ & $4(15)$ \\
\hline M6 & $0(0)$ & $0(0)$ \\
\hline M7 & $0(0)$ & $0(0)$ \\
\hline Not classified & $1(8)$ & $6(22)$ \\
\hline \multicolumn{3}{|l|}{ Cytogenetic risk group, n (\%) } \\
\hline Favorable & $2(17)$ & $4(15)$ \\
\hline Intermediate & $10(83)$ & $13(48)$ \\
\hline Poor & $0(0)$ & $9(33)$ \\
\hline Insufficient sample & $0(0)$ & $1(4)$ \\
\hline \multicolumn{3}{|l|}{ Induction therapy response, $n(\%)$} \\
\hline$C R$ & $7(70)$ & $15(88)$ \\
\hline Failure & $3(30)$ & $2(12)$ \\
\hline
\end{tabular}

\section{Methods}

Patients

The clinical characteristics of AML patients with FLT3/ITD mutation and FLT3/ITD wild type and correlation with different FAB subtypes are demonstrated in Table 1.

Thirty-four consecutive, unselected, newly diagnosed, and untreated AML adult patients were analyzed at diagnosis for the expression of CD123 in the total blast population and at stem cell level as defined by CD34+/CD38-. Diagnoses were established according to criteria proposed by the French-American-British (FAB) study group [20]. The patients' characteristics are shown in Table 2.

\section{Controls}

For control purposes, we examined normal bone marrow (BM) cells obtained from five healthy volunteers. All controls were treated in the same manner as patient samples. 
Table 2 Patient characteristics

\begin{tabular}{|c|c|}
\hline Patient characteristics & Total (\%) \\
\hline No. of patients & 34 \\
\hline Male/female & $24 / 10$ \\
\hline Age at diagnosis, mean (range) & $63(23-86)$ \\
\hline$\%$ blasts at diagnosis (morphology), mean (range) & $41.5(20-96)$ \\
\hline \% blasts at diagnosis (flow), mean (range) & $42.5(9-86)$ \\
\hline WBC count at diagnosis, $10^{9} / \mathrm{L}$, median (range) & $4.5(0.71-179)$ \\
\hline De novo/secondary AML & $27(79) / 7(21)$ \\
\hline \multicolumn{2}{|l|}{ FAB classification, $n(\%)$} \\
\hline$M_{0}$ & $0(0)$ \\
\hline$M_{1}$ & $8(24)$ \\
\hline$M_{2}$ & $10(29)$ \\
\hline$M_{3}$ & $1(3)$ \\
\hline $\mathrm{M}_{4}$ & $2(6)$ \\
\hline $\mathrm{M}_{5}$ & $4(12)$ \\
\hline$M_{6}$ & $1(3)$ \\
\hline$M_{7}$ & $0(0)$ \\
\hline Not classified & $8(24)$ \\
\hline \multicolumn{2}{|l|}{ Cytogenetic risk group, $n$ (\%) } \\
\hline Favorable & $2(6)$ \\
\hline Intermediate & $19(56)$ \\
\hline Poor & $12(35)$ \\
\hline No metaphases & $1(3)$ \\
\hline \multicolumn{2}{|l|}{ FLT3/ITD, n (\%) } \\
\hline Present & $10(29)$ \\
\hline Absent & $15(44)$ \\
\hline Not analyzed & $9(26)$ \\
\hline \multicolumn{2}{|l|}{ CD123, n (\%) } \\
\hline Present & $32(94 \%)$ \\
\hline Absent & $2(6 \%)$ \\
\hline
\end{tabular}

\section{Study conduct}

All patients and controls gave their informed consent for participation in the current evaluation after having been advised about the purpose and investigational nature of the study as well as potential risks. The study design was approved by the Research Ethics Committee of the Royal Adelaide Hospital, South Australia prior to its initiation.

\section{Monoclonal antibodies}

A number of commercial monoclonal antibodies (MoAbs) (against CD13, CD33, CD38, CD123, CD45, CD34, CD117, and HLA-DR) were used to characterize and isolate leukemic stem cells. A list of MoAbs is shown in Table 3. To determine expression of $\mathrm{CD}$ antigens on blasts and leukemic stem cells, combinations of CD13/CD33/CD38/ CD123/CD45/CD34/CD117/HLA-DR were applied.
Table 3 Specification of monoclonal antibodies

\begin{tabular}{lllll}
\hline Antibody & Clone & Isotype & Conjugate & Source \\
\hline CD13 & L138 & $\operatorname{lgG1}$ & PE & Beckton Dickinson \\
CD33 & P67.6 & $\operatorname{lgG1}$ & PE & Beckton Dickinson \\
CD33 & P67.6 & $\operatorname{lgG1}$ & FITC & Beckton Dickinson \\
CD34 & $8 \mathrm{G} 12$ & $\operatorname{lgG1}$ & FITC & Beckton Dickinson \\
CD34 & 581 & $\operatorname{lgG1}$ & PC5 & ImmunoTech \\
CD38 & LS198-4-3 & $\operatorname{lgG1}$ & PE & Beckman Coulter \\
CD45 & Immu19.2 & $\operatorname{lgG1}$ & PC5 & ImmunoTech \\
CD45 & J33 & $\operatorname{lgG1}$ & ECD & ImmunoTech \\
CD117 & $104 D 2 D 1$ & $\operatorname{lgG1}$ & PE & ImmunoTech \\
CD117 & $104 D 2 D 1$ & $\operatorname{lgG1}$ & PC7 & Beckman Coulter \\
CD123 & $9 F 5$ & $\operatorname{lgG1}$ & PE & Beckton Dickinson \\
HLA-DR & L243 & $\operatorname{lgG2a}$ & FITC & BioDesign \\
CD38 & T16 & $\operatorname{lgG1}$ & FITC & Beckman Coulter \\
\hline
\end{tabular}

Five-color multiparameter flow cytometry and characterization of CD34+/CD38-/CD123+ cells

Heparinized bone marrow cells ( 106/tube) were incubated with combinations of MoAbs at room temperature for $15 \mathrm{~min}$. Erythrocytes were then lysed in $2 \mathrm{~mL}$ FACSTM lysing solution (Becton Dickinson, San Diego, CA, USA). Cells were consequently washed and analyzed on a Cytomics FC500 flow cytometer and CytomicsTM CXP Analysis Version 1 Software (Beckman Coulter, USA).

Leukemic progenitors were defined by their phenotype (CD34+, CD45+, CD38-, CD123+) using CD45 gating strategy [21] and CD34 and/or CD117 backgating strategy to better define the blast population as previously described by our group [22]. Control tubes stained with an isotype-matched control were included in all experiments and were used to define the cutoff point for positive/negative staining.

The gating strategy in newly diagnosed AML to identify CD34+/CD38-/CD123+ cells is as shown in Fig. 2. After labeling of AML cells with the appropriate antibody combinations, the CD34+/CD38- cells were identified by a CD45 $\mathrm{dim} / \mathrm{SS}$ low strategy based on CD34 backgating (Fig. 2a), gating on blasts characterized by CD45 dim/low side scatter (SSC) (Fig. 2b), and gating of the blasts within the gate defined by forward scatter (FSC) and SSC to identify a population that is roughly homogeneous for scatter properties (Fig. 2c). The CD38-, CD34+ and CD123+ population were defined using isotype matching as a negative control (Fig. 2d, e). Cells from the FSC/SSC plot defined in Fig. 2c are shown in Fig. $2 \mathrm{~g}, \mathrm{~h}$ in a plot defined by CD34 and CD38 expression. The CD34+/CD38- population defined in Fig. $2 \mathrm{~g}, \mathrm{~h}$ is gated in a FSC/SSC plot to identify a CD34+/CD38- population with homogeneous scatter properties (Fig. 2i). The frequency of this determined CD34+/CD38- population was used in this study. Cells 
from the FSC/SSC plot defined in Fig. 2i are shown in Fig. 2j, k in a plot defined by CD34 and CD123 expression. The CD34+/CD38-/CD123+ population defined in Fig. 2j, $k$ is gated in a FSC/SSC plot to identify a CD34+/CD38-/CD123+ population with homogeneous scatter properties Fig. $2 \mathrm{l}$.

The gating strategy in normal $\mathrm{BM}$ to identify CD34+/CD38-/CD123+ is as shown in Fig. 3; after labeling of normal BM cells with the appropriate antibody combinations, the CD34+ cells were identified by a CD45 dim/SS low and CD34+ backgating strategy (Fig. 3a-c). Gating on CD34+ cells and blasts characterized by CD45 dim/low SSC showing in red (Fig. 3c). The $\mathrm{CD} 38+$ and $\mathrm{CD} 123+$ population were defined using isotype matching as a negative control and backgating of the positive cells for CD123 (Fig. 3d, e) and CD38 (Fig. 3g, h) in total population. The positive cells for CD123 are showing in blue (Fig. 3f) and in pink (Fig. 3i) for CD38 in CD45/SSlog dot plot. Cells from the plot defined in Fig. 3b are shown in Fig. 3j in a plot defined by CD34 and CD38 expression. The frequency of the CD34+/CD38- cells determined CD34+/CD38- population was used in this study. The frequency CD34+/CD38-/CD123+ and CD34+/CD38-/CD123- population was defined in Fig. 3k in a plot defined by CD34 and CD123.

\section{Isolation of $\mathrm{CD} 34+$ cells}

The isolation of CD34+ cells was performed on mononuclear cells (MNC) from the BM of 34 AML patients. MNC were washed twice with MACS CD34+ buffer, and CD34+ progenitor cells were purified using a MACS CD34+ progenitor cell selection isolation kit (Miltenlyi Biotech, Germany) according to the manufacturer's instructions. The purity of CD34+ cells following the isolation procedure was calculated by staining with an anti-CD34-PC5.

\section{Sorting of leukemic stem cells CD34+/CD38-/CD123+}

We sorted the CD34+/CD38- population into the putative LSC population CD34+/CD38-/CD123+ and the putative normal hematopoietic stem cell (HSC) population CD34+/CD38-/CD123- using BD FACSARIA ${ }^{\text {ma }}$ Cell Sorter (BD Biosciences, San Jose, CA 95,131, USA). Cells were incubated with a phycoerythrin (PE)-conjugated CD123 MoAb, a fluorescein isothiocyanate (FITC) CD38 MoAb, and a phycoerythrin-Cy5 (PC5)conjugated $\mathrm{CD} 34 \mathrm{MoAb}$ in $\mathrm{AB}$ serum at room temperature for $15 \mathrm{~min}$. Then, cells were washed, and the CD34+/CD38-/CD123+ fraction of cells isolated in a BD FACSARIATM Cell Sorter. Pools of cells expressing similar level of CD34+/CD38-/CD123+ and CD34 $+/ \mathrm{CD} 38-/ \mathrm{CD} 123-$ were collected. After sorting, the purity of CD34+/CD38-/CD123+ AML cells was $>95 \%$.

\section{Polymerase chain reaction for FLT3}

We isolated genomic deoxyribonucleic acid (DNA) from the purified sorted population using a QIAamp Mini Kit (QIAGEN) and polymerase chain reaction (PCR) was performed using primers flanking the (JM) coding region: 11F (GCAATTTAGGTATGAAAGCCAGC) and 12R (CTTTCAGCATTTTGACGGCAACC) previously described by Nakao et al. [16]. The amplification was performed on DNA Thermal Cycler (Eppendorf Mastercycler) and entailed an initial denaturation of $94{ }^{\circ} \mathrm{C}$ for $7 \mathrm{~min}$, followed by 35 cycles of denaturation at $94{ }^{\circ} \mathrm{C}$ for $1 \mathrm{~min}$, annealing at $62{ }^{\circ} \mathrm{C}$ for $1 \mathrm{~min}$, and extension at $72{ }^{\circ} \mathrm{C}$ for $1 \mathrm{~min}$, with a final extension at $72{ }^{\circ} \mathrm{C}$ for $7 \mathrm{~min}$. PCR products were resolved on $2 \%$ agarose gels and visualized under ultraviolet light after ethidium bromide staining. The characteristic doublet of the FTL3/ITD mutation is easily visualized after electrophoresis. Genomic DNA from known positive and negative cases was used as controls.

\section{Optimization of the PCR technique for low DNA concentrations}

To optimize the PCR method for very low DNA concentrations obtained from very few numbers of cells, a study was conducted using different DNA amounts 50, 25, and $12.5 \mathrm{ng}$ with $15 \mu \mathrm{l}$ PCR reaction mix, in a total volume of $25 \mu \mathrm{l}$ in duplicate from an AML patient positive for FLT3/ITD. The results of this experiment revealed that FLT3/ITD could be detected at 5, 2.5, and $1.25 \mathrm{ng} / \mu \mathrm{l}$ DNA as shown in Fig. 1a. Thus, we used 12.5 ng DNA in sorting experiments for PCR.

\section{Sequencing}

Two of the ITD mutations identified during the assay validation were cycle sequenced in the forward and reverse direction to verify the results. PCR products were purified using QIAQuick columns (QIAGEN) and cycle sequenced using Big Dye, Version 2 (Applied Biosystems) according to the manufacturer's protocol. For sequencing the ITD, PCR primers 11F (5'-GCAATTTAGGTATGAAAGCCAGC-3') and 12R (5'-CTTTCAGCATTTTGACGGCAACC-3') of exons 14 and 15 were used. Sequences were aligned and examined using Mutation SurveyorTM software.

\section{Results \\ Expression of CD123 (IL-3 a receptor) in AML blast cells}

Thirty-four AML patients at diagnosis were tested for the expression of $\mathrm{CD} 123$ in the total blast population and at the stem cell level as defined by CD34+/CD38-.

CD123 was expressed in 32 of 34 (94\%) AML patients. The median expression in the whole blast population was $86 \%$ (range, 20-99\%). In 24 (75\%) patients, the majority of blasts $(>60 \%)$ expressed CD123 and in the remaining $8(25 \%)$ patients, only a subset of blasts expressed CD123 (Table 2). 
a

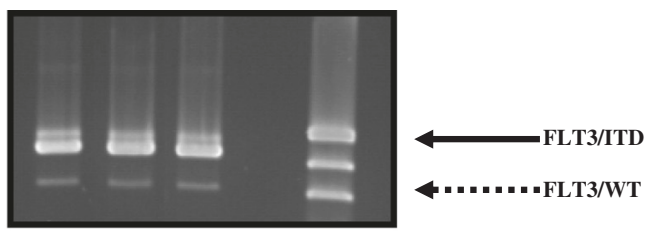

$\begin{array}{lllll}1 & 2 & 3 & 4 & M\end{array}$

b

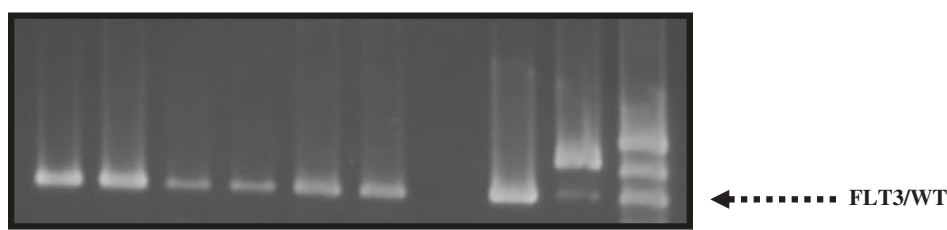

$\begin{array}{llllllllll}1 & 2 & 3 & 4 & 5 & 6 & 7 & 8 & 9 & M\end{array}$

c

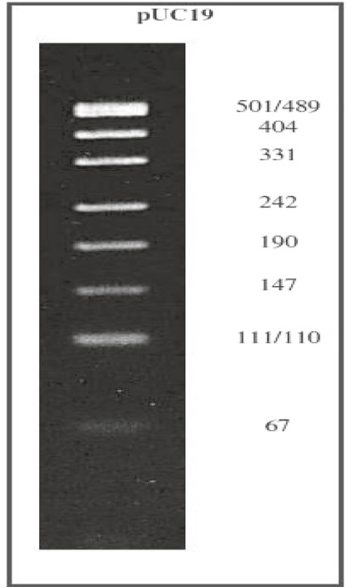

Fig. 1 Optimization of PCR technique using FLT3/TDD-positive and FLT3/TTD-negative patient. a Using three different DNA concentrations 5, 2.5, and $1.25 \mathrm{ng} / \mathrm{Ml}$ in FLT3/TTD-positive AML patient. Lane 1 FLT3/TTD detected with $50 \mathrm{ng}$ DNA added, lane 2 FLT3/TD detected with 25 ng DNA added, lane 3 FLT3/TD detected with $12.5 \mathrm{ng}$ DNA added, lane 4 no DNA added, and M pUC19 molecular marker. The solid line points to FLT3/TTD bp inserted while the dotted arrow points to the WT FLT3 gene. $\mathbf{b}$ Using DNA obtained from different number of cells $\left(2 \times 10^{6}, 150,1606\right.$ cells in duplicates) on WT FLT3 AML patient based on the number of cells obtained from the first sorted sample (sample no.1 in Table 4). Lanes 1 and 2 (duplicate) DNA obtained from $2 \times 10^{6}$ cells, FLT3 WT detected; lanes 3 and 4 (duplicate) DNA obtained from 150 cells, FLT3 WT detected; lanes 5 and 6 (duplicate) DNA obtained from 1606 cells, FLT3 WT detected; lane 7, no DNA, so the PCR was specific; lanes 8 and 9 are the negative and positive controls and M was pUC19 marker. c DNA fragments (bp) of the molecular marker pUC19

\section{Expression of CD123 (IL-3 a receptor) in AML stem cells CD34+/CD38-}

The expression of CD123 on the stem cell fraction as defined by CD34+/CD38- was tested using CD45 and CD34 backgating strategy outlined in Fig. 2. Four patients were CD34 negative, and therefore, the estimation of CD123 expression in the CD34+/CD38- compartment was not possible. Two of these patients were M5a (generally most of M5a patients are CD34 negative), one M1 and one M3 (in most cases, M3 are also CD34 negative) FAB classification. CD123 was strongly expressed in the CD34+/CD38- cells (96 $\pm 2 \%$ positive) from $28(87.5 \%)$ of 32 primary specimens.

\section{Expression of CD123 (IL-3 a receptor) in normal BM CD34+/CD38- fraction}

Five normal BMs were tested for the expression of CD123 on CD34+/CD38- cells, and they were all CD123 negative. The median level of CD123 in normal CD34+/CD38- stem cells $(0.119 \%)$, range (0.004-1.43\%) in the five normal BMs (Fig. 3).

\section{Sorting AML stem cells}

We analyzed FLT3 mutation status in 25 of 32 (78\%) patients who expressed CD123, 10 were FLT3/ITD positive and 15 were wild type (WT). 


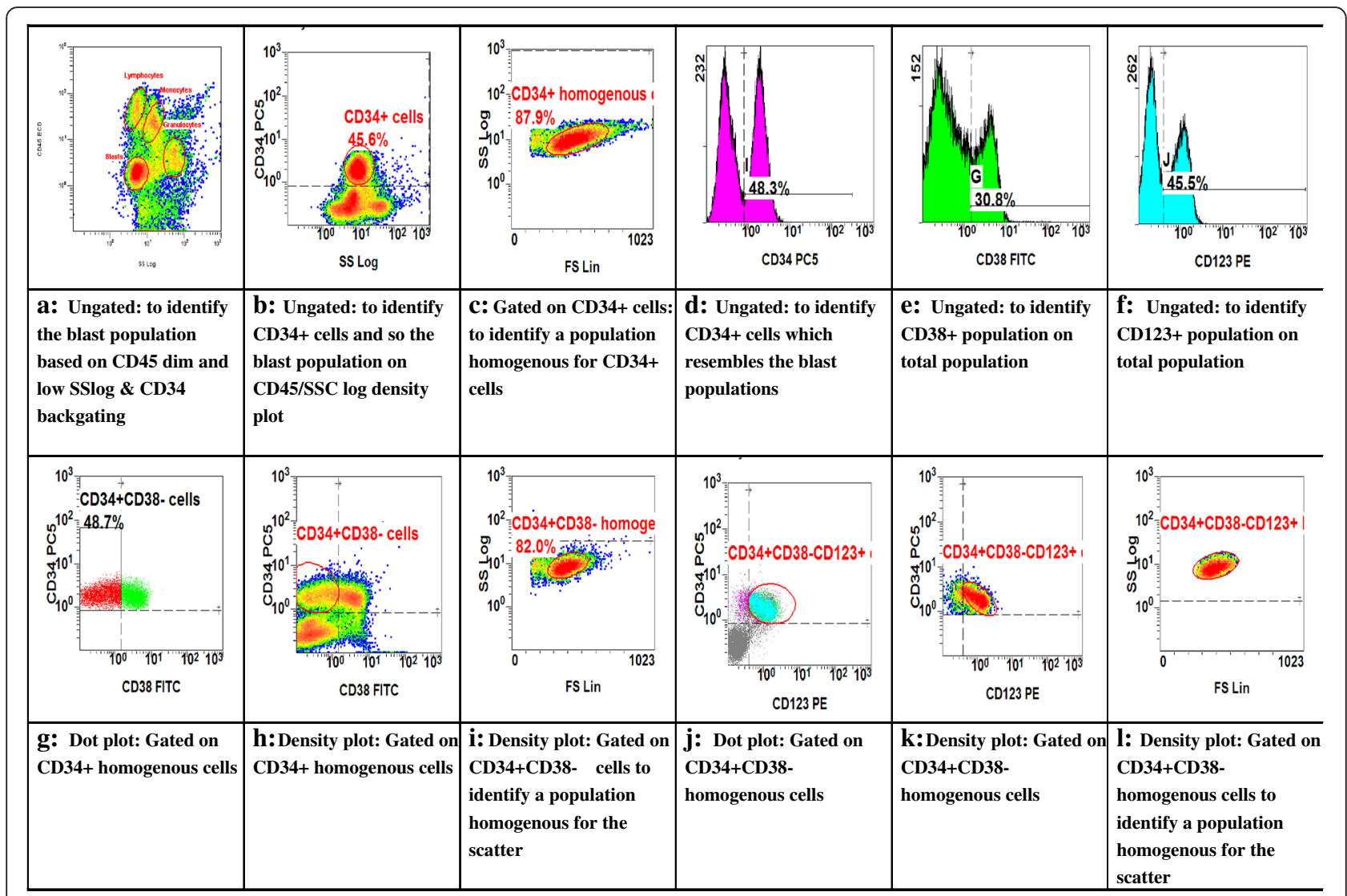

Fig. 2 Gating strategy in newly diagnosed AML to identify CD34+/CD38-/CD123+ cells

To determine the expression of FLT3/ITD in AML stem cells, highly purified (purity >95\%) CD34+/CD38-/CD123 + and CD34+/CD38-/CD123- cells were examined for FLT3/ITD mutation in seven patients with FLT3/ITD-positive AML as demonstrated in Fig. 4. We were unable to perform analysis in the remaining three FLT3/ITD-positive patients because of insufficient material. The numbers of CD34+/CD38-/CD123+ cells sorted ranged from 150 to 300,000 cells, and 16 to 148,396 cells for CD34+/CD38-/CD123- cells (Table 4). Immunomagnetic cell selection (MACS) was used to enrich CD34 cells from patient no. 4 , as CD34 in this patient was only $2.3 \%$ (Table 4 ).

All of CD34+/CD38-/CD123+ fractions amounted to less than $1 \%$ of the total cells except sample number 6 . In addition, with the exception of sample number 3, all of CD34+/CD38-/CD123- fractions also amounted to less than $1 \%$ of the total cells (Table 4).

\section{Detection of FLT3/ITD in the sorted AML stem cells}

Genomic DNA from unsorted and sorted cells was isolated and PCR was performed using primers flanking exons 14 and 15 of the FLT3 gene [23, 24]. In the seven positive FLT3/ITD samples analyzed, the mutation was detected in the LSC-enriched fraction CD34+/CD38-/CD123+ (Fig. 4a). In six patients, CD34+/CD38-/CD123- cells were FLT3/ITD negative. In the remaining patient, it is possible that no true CD123- cells were obtained as CD123 was expressed on $99.2 \%$ of CD34+/CD38cells and very low numbers of cells were collected in CD34+/CD38-/CD123- fraction (69 cells only).

In sample 1, the mutation in LSC-enriched fraction CD34+/CD38-/CD123+ was most likely present in homozygous form, as less than $1 \%$ of the PCR product represented the WT FLT3 gene. In samples 2, 3, 4, 5, 6, and 7, the mutations were present in heterozygous form, as approximately $50 \%$ of the PCR product represented the WT FLT3 gene, demonstrated by thickness of the band (Fig. 4a).

\section{Sequencing the FLT3/ITD}

The FLT3/ITD mutations in the CD34+/CD38-/CD123+ cells were sequenced in two patients (patients 3 and 4) (Fig. 4b) to confirm that they represented the identical mutations present in the sorted and unsorted original samples. In one patient, 33 base pairs (bp) inserted, and the 


\begin{tabular}{|c|c|c|c|c|c|}
\hline 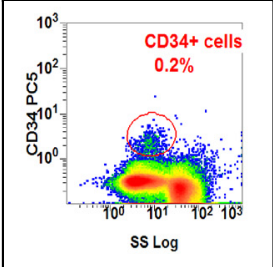 & 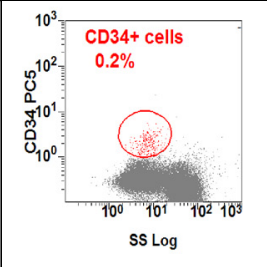 & 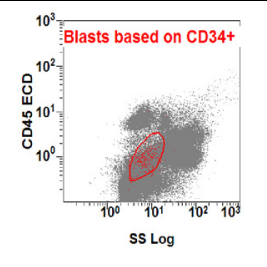 & 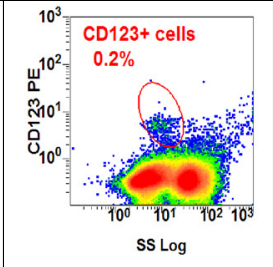 & 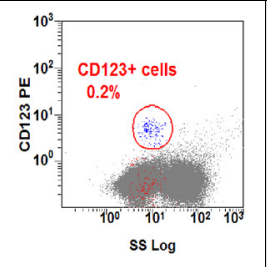 & 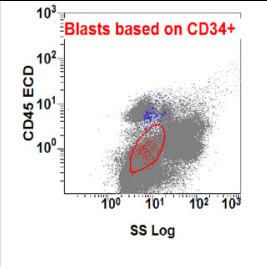 \\
\hline $\begin{array}{l}\text { a:Ungated: Density plot, } \\
\text { gate on CD34+ cells on } \\
\text { total population }\end{array}$ & $\begin{array}{l}\text { b: Ungated: Dot plot, } \\
\text { gate on CD34+ cells on } \\
\text { total population showing } \\
\text { in red }\end{array}$ & $\begin{array}{l}\text { c: Ungated: Dot plot, } \\
\text { gate on CD34+ cells in } \\
\text { CD45/SSlog based on } \\
\text { CD34+ backgating }\end{array}$ & $\begin{array}{l}\text { d: Ungated: Density plot, } \\
\text { gate on CD123+ cells on } \\
\text { total population }\end{array}$ & $\begin{array}{l}\text { e: Ungated: Dot plot, } \\
\text { gate on CD123+ cells on } \\
\text { total population showing } \\
\text { in blue }\end{array}$ & $\begin{array}{l}\text { f: Ungated: Dot plot, } \\
\text { gate on CD34+ cells in } \\
\text { CD45/SSlogbased on } \\
\text { CD34+ backgating, the } \\
\text { dot plot shows the } \\
\text { location of CD123+ cells. }\end{array}$ \\
\hline 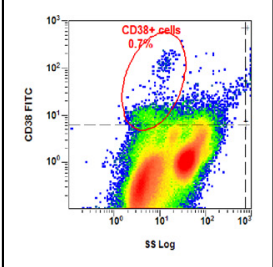 & 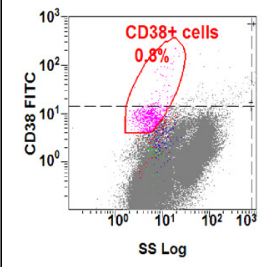 & 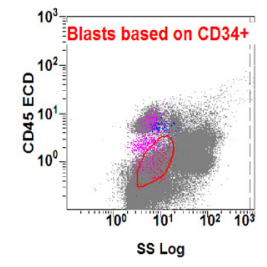 & 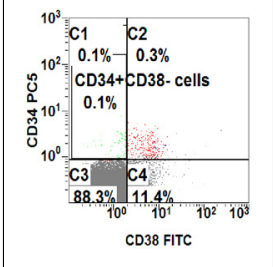 & 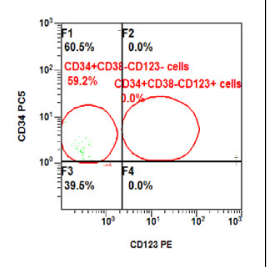 & \\
\hline $\begin{array}{l}\text { g: Ungated: Density plot, } \\
\text { gate on CD38+ cells on } \\
\text { total population }\end{array}$ & $\begin{array}{l}\text { h: Ungated: Dot plot, } \\
\text { gate on CD38+ cells on } \\
\text { total population showing } \\
\text { in pink }\end{array}$ & $\begin{array}{l}\text { i: Ungated: Dot plot, gate } \\
\text { on CD34+ cells in } \\
\text { CD45/SSlog based on } \\
\text { CD34+ backgating, the } \\
\text { dot plot shows the } \\
\text { location of CD38+ cells. }\end{array}$ & $\begin{array}{l}\text { j: Gated on CD34+ cells, } \\
\text { another gate was created } \\
\text { on CD34+CD38 cells }\end{array}$ & $\begin{array}{l}\text { k: Gated on } \\
\text { CD34+CD38 cells, } 2 \\
\text { gates were created one } \\
\text { on } \mathrm{CD34+CD38CD123+} \\
\text { and } \mathrm{CD34+CD38} \\
\text { CD123 }\end{array}$ & \\
\hline
\end{tabular}

Fig. 3 Gating strategy in normal BM to identify CD34+/CD38-/CD123+ cells

other one was $78 \mathrm{bp}$ inserted. The fact that this expanded population of LSCs contained the identical FLT3/ITD mutation as was observed in the original unsorted samples constitutes evidence that the FLT3/ITD mutations were present in LSCs.

\section{Discussion}

In this study, we hypothesized that the FLT3/ITD mutation occurs at a stage of stem cells defined by CD34+/CD38and IL-3 $\alpha$ receptor in AML patients, and FLT3/ITD may be a primary and not a secondary event in leukemogenesis.

We have identified that expression of CD123 is found on virtually almost all (94\%) AML specimens examined similar to previously published data $[8,25,26]$. The high levels of expression observed could simply be indicative of some other conserved event in leukemogenesis. Furthermore, CD123 expression was also demonstrated on the primitive subpopulation of CD34+/CD38- cells (28 of 32 specimens).

The presence of CD123 on AML CD34+/CD38- cells has a potential significance. It demonstrates that LSCs are biologically distinct from their normal stem cell counterparts. In addition, because CD123 is not found on normal HSCs, it provides a unique marker that can be used to identify the malignant clone. This feature may be very useful in minimal residual disease studies as a single and standardized marker [27-29]. Furthermore, the CD123 epitope represents a target to which therapeutic strategies may be directed $[8,25,26,30-32]$.

Somatic mutation of FLT3 involving ITDs of the JM domain have been identified in approximately $17-34 \%$ of AML cases [16, 17, 33-37]. Two studies demonstrated the presence of FLT3 mutations at LSC level [37, 38]. Levis et al. [38] sorted primary AML samples harboring FLT3/ITD mutations into stem cell-enriched CD34+/CD38- fractions and then analyzed the sorted and unsorted cells for the FLT3 mutant-WT ratio. In each case, the FLT3 mutant-WT ratio was not changed by selection of CD34+/CD38- cells, implying that the mutations occurred in the LSCs. The stem cell-enriched fraction engrafted non-obese diabeticsevere combined immunodeficient (NOD/SCID) mice, and the FLT3/ITD mutation was present in the resultant engrafted marrow. In addition, the finding that BM cells from patients with AML harboring FLT3/ITD mutations had a greater capacity to engraft NOD/SCID mice than cells from patients lacking such mutations also supports the hypothesis that FLT3/ITD is present at LSC level and hence more likely to engraft the NOD/SCID mice $[39,40]$. 


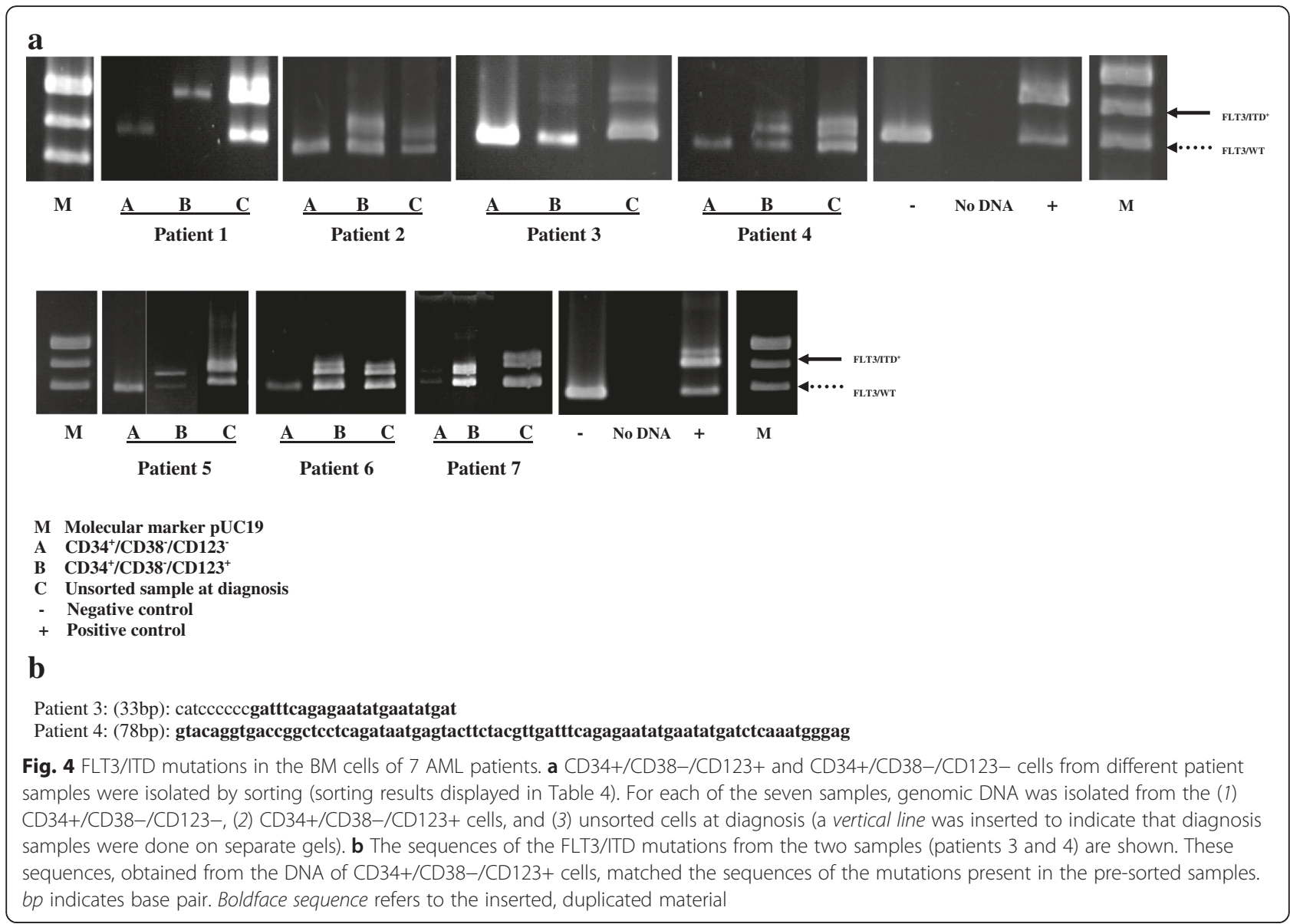

We demonstrate that FLT3/ITD mutations are found in a primitive fraction of cells as defined by CD34+/CD38-/CD123+. In addition, our data show that the FLT3/ITD mutations were present within purified enriched LSCs defined by CD123 and absent within stem cells without CD123. The specimens were derived from several different FAB subtypes M1, M2, M4, and M5a, and therefore, represent a broad cross section of commonly detected AML types.

The sorted cells in most of the samples comprised less than $1 \%$ of the total population before sorting. If CD34+/CD38-/CD123+ subset contains a significant fraction of LSCs, then the FLT3/ITD imply that most of these mutations are in cells capable of self-renewal [19]. Ideally, these enriched leukemic cells should be injected into NOD/SCID mice but this was technically challenging as an appropriate AML model was not available in the country.

In sample 1, after sorting of the CD34+/CD38-/CD123+ fraction, no WT signal was detectable, probably as a result of eliminating the small percent of normal hematopoietic cells in the sample. In all other six cases, the FLT3/ITD was very similar between sorted and unsorted fractions as shown in Fig. 4. In no case was the mutant allele depleted or enhanced by sorting for LSCs. It is interesting to note that the six samples were heterozygous for FLT3/ITD, even in the stem cell-sorted fractions. It is possible that this reflects a PCR bias for the shorter WT molecule and that this ratio actually represents $100 \%$ of cells with a heterozygous mutation. Alternately, these ratios may suggest the presence of either additional sub clones of leukemic CD34+/CD38-/CD123+ cells that lacked the mutation within these samples.

FLT3-ITD mutation may occur in the early phase of leukemia pathogenesis, even blast cell with FLT3-ITD mutation are eliminated by chemotherapy, the aberrant mutation that pre-existed in LSC could still play an indispensable role in the relapse of the leukemia [41-43], and our data provided new insights into the pathogenesis of LSC.

Several lines of evidence have previously suggested that these mutations can occur relatively late in the development of leukemia. Few studies have demonstrated that in a small proportion of cases, FLT3/ITD mutations 
Table 4 Summary of results from sorting and immunomagnetic cell selection MACS

\begin{tabular}{|c|c|c|c|c|c|c|c|c|c|c|c|}
\hline Sample no. & Age & $\begin{array}{l}\text { Total unsorted } \\
\text { cells }\end{array}$ & $\begin{array}{l}\% \text { CD34 unsorted } \\
\text { cells }\end{array}$ & $\begin{array}{l}\% \text { CD123 unsorted } \\
\text { cells }\end{array}$ & $\begin{array}{l}\text { Total CD34+/CD38-/ } \\
\text { CD123+ cells from } \\
\text { the sorter }\end{array}$ & $\begin{array}{l}\text { Total CD34+/CD38-/ } \\
\text { CD123- cells from } \\
\text { the sorter }\end{array}$ & $\begin{array}{l}\text { WBC count } \\
\times 10^{9} / L\end{array}$ & FAB-subtype & Cytogenetics & $\begin{array}{l}\% \text { blast } \% \\
\text { diagnosis }\end{array}$ & $\begin{array}{l}\text { Sequencing } \\
\text { FLT3/ITD }\end{array}$ \\
\hline 1 & 46 & $10 \times 10^{6}$ & 96 & 86 & 150 & 1606 & 5.6 & M1 & Normal & 80 & ND \\
\hline 2 & 60 & $18 \times 10^{6}$ & 89 & 99 & 76,000 & 418 & 4.5 & M1 & Normal & 62 & ND \\
\hline 3 & 69 & $12 \times 10^{6}$ & 91 & 86 & 12,674 & 148,396 & 14.4 & M2 & Normal & 22 & $78 \mathrm{bp}$ \\
\hline 4 & 53 & $27 \times 10^{6}$ & $73^{\mathrm{a}}$ & 93 & 1839 & 16 & 179 & M5a & Normal & 82 & $33 \mathrm{bp}$ \\
\hline 5 & 62 & $30 \times 10^{6}$ & 10 & 64 & 559 & 164 & 145 & M4 & Normal & 40 & ND \\
\hline 6 & 65 & $17 \times 10^{6}$ & 15 & 99 & 300,000 & 69 & 6.11 & M2 & Normal & 73 & ND \\
\hline 7 & 72 & $40 \times 10^{6}$ & 79 & 68 & 640 & 3602 & 0.92 & M1 & Normal & 26 & ND \\
\hline
\end{tabular}

Total unsorted cells represents the starting sample size, whereas total CD34+CD38-CD123+ and CD34+CD38-CD123- cells refers to the total number of CD34+/CD38-/CD123+/- cells obtained from a given sample after sorting. Genomic DNA was sequenced for FLT3/ITD for sample nos. 3 and 4. ND indicates not done

aAfter CD34+ selection by MACS, the total yield of CD34+ $=2.4 \times 10^{-5}$ cells 
are lost at relapse [44-48]. This suggests that, in these few cases, the mutations occurred in a subclone that was eliminated by treatment. Until now, the observation of an increased outgrowth of FLT3/ITD AML in NOD/ SCID mice suggests that in a large part of the FLT3/ ITD-positive leukemia, the mutation is present at the level of the malignant stem cell $[19,49]$. Nevertheless, it is not clear if the observed outgrowth is solely dependent on the transplanted LSCs or that also other, more committed, cells are able to expand in this model. The occurrence of an enhanced survival of FLT3/ITD AML cells is further supported by the observations of Schnitgger et al. [33] and Kottaridis et al. [45] who observed that FLT3/ITD patients who relapsed for the greater part showed an increased mutant to WT ratio at relapse.

Our results are not consistent with the previous findings of occasional loss of FLT3/ITD mutations at relapse. However, our results do not exclude that at least a subset of AML, the FLT3/ITD mutations are present only in subclones derived from the original LSC, subclones that lack the capacity for self-renewal. It may be that our sample size was simply not large enough to uncover such cases. These may represent the cases in which the mutation arose as a relatively late hit in leukemogenesis and may be the cases in which the mutation is lost at relapse. Alternately, FLT3 mutations could always be present in LSCs, but occasionally chemotherapy succeeds in eradicating the FLT3/ ITD samples, whereas other LSCs that lack the mutation are resistant.

In the study of Masao et al. [50], they identified target genes of the FLT3/ITD by microarray expression profiling. ITD mutations induced transcriptional programs that partially mimicked IL-3 activity with many genes being specifically regulated by the mutations but not by ligand-activated WT FLT3. They also have shown that FLT3/ITD mutations induce a transcriptional program that is fundamentally different from the program induced by FLT3-WT.

The sorting strategy used in this study implemented stringent criteria for scoring, as the purity of sorting was $>95 \%$ in all the seven AML patients. We also optimized the PCR for very small number of cells and were able to demonstrate the presence of FLT3/ITD in CD34+/CD38-/CD123+ fraction and not CD34+/CD38-/CD123-. This confirms that the PCR technique was robust (with the exception of one patient) which gives evidence that the technique is working on small number of cells.

Targeting of CD123/IL-3 alpha receptor may be a novel promising treatment approach in patients with CD123+ AML $[8,25,27,51-53]$. This concept is based on the notion that in most patients with AML, myeloblasts express CD123 as shown in our study.

\section{Conclusions}

In conclusion, these novel findings show that FLT3/ITD mutations are present at the leukemic stem cell level and may be a primary and not secondary event in leukemogenesis. There is also evidence to suggest that FLT3/ITD mutations were present within purified enriched leukemic stem cells defined by CD123 (CD34+CD38-CD123+) and absent within stem cells without CD123 (CD34+CD38-CD123-). Furthermore, the study shows that the oncogenic events of FLT3/ITD happen at a cell stage possessing the alpha chain of the IL-3 receptor (CD123). These novel findings provide a rationale for treatment involving CD123-trageting antibodies with intracellular FLT3 inhibitors directed against AML stem cells.

In the future, it would be of great interest to study the frequency of CD34+/CD38-CD123+ cells post induction and consolidation chemotherapy as these cells may represent the highly resistant cells to chemotherapy and might be the cells that cause regrowth of leukemia and thus relapse of the disease.

\section{Abbreviations \\ $A M L$, acute myeloid leukemia; $B M$, bone marrow; $C R$, complete remission; DNA, deoxyribonucleic acid; FAB, French-American-British; FITC, fluorescein isothiocyanate; FLT3, FMS-like tyrosine kinase 3; FSC, forward scatter; IL-3, interleukin-3; ITD, internal tandem duplication; LSC, leukemic stem cell; MNC, mononuclear cells; MoAbs, monoclonal antibodies; NOD/SCID, non-obese diabetic/severe combined immunodeficiency; PC5, phycoerythrin cyanin 5; $P C R$, polymerase chain reaction; $P E$, phycoerythrin; SCID, severe combined immunodeficient; SSC, side scatter}

\section{Acknowledgements}

We gratefully acknowledge Mr. Avinash Daniel Pinto for the technical assistance. The authors would also like to acknowledge The Research Council of Oman (TRC) for the financial support (TRC Grant Number 47).

\section{Funding}

This study is funded by The Research Council of Oman (TRC) (Grant Number 47) and The Australian Rotary Health Research Fund/Rotary Club of Williamstown. The funding bodies were not involved in the design of the study and collection, analysis, interpretation of data, and in writing the manuscript.

\section{Availability of data and materials}

The datasets can be shared upon acceptance of the manuscript.

\section{Authors' contributions}

AM designed and performed the experiments. AM drafted the manuscript. IL and DG gave supervisory support while conducting the study and provided intellectual input on the draft. All authors read and approved the final manuscript.

\section{Competing interests}

The authors declare that they have no competing interests.

\section{Consent for publication}

Not applicable.

\section{Ethics approval and consent to participate}

The study design was approved by the Research Ethics Committee of the Royal Adelaide Hospital, South Australia prior to its initiation.

Received: 6 March 2016 Accepted: 21 July 2016

Published online: 27 July 2016 


\section{References}

1. Lowenberg B, Downing JR, Burnett A. Acute myeloid leukemia. N Engl J Med. 1999;341(14):1051-62.

2. Bachas C, Schuurhuis G, Assaraf Y, Kwidama Z, Kelder A, Wouters F, Snel A, Kaspers $\mathrm{G}, \mathrm{Cloos} J$. The role of minor subpopulations within the leukemic blast compartment of AML patients at initial diagnosis in the development of relapse. Leukemia. 2012;26(6):1313-20.

3. Blair A, Hogge DE, Sutherland HJ. Most acute myeloid leukemia progenitor cells with long-term proliferative ability in vitro and in vivo have the phenotype CD34(+)/CD71(-)/HLA-DR. Blood. 1998;92(11):4325-35.

4. Bonnet $D$, Dick JE. Human acute myeloid leukemia is organized as a hierarchy that originates from a primitive hematopoietic cell. Nat Med. 1997;3(7):730-7.

5. Terpstra W, Ploemacher RE, Prins A, van Lom K, Pouwels K, Wognum AW, Wagemaker G, Lowenberg B, Wielenga JJ. Fluorouracil selectively spares acute myeloid leukemia cells with long-term growth abilities in immunodeficient mice and in culture. Blood. 1996;88(6):1944-50.

6. Ishikawa F, Yoshida S, Saito Y, Hijikata A, Kitamura H, Tanaka S, Nakamura R, Tanaka T, Tomiyama H, Saito N. Chemotherapy-resistant human AML stem cells home to and engraft within the bone-marrow endosteal region. Nat Biotechnol. 2007;25(11):1315-21.

7. Al-Mawali A, To L, Gillis D, Hissaria P, Mundy J, Lewis I. The presence of leukaemia-associated phenotypes is an independent predictor of induction failure in acute myeloid leukaemia. Int J Lab Hematol. 2009:31(1):61-8.

8. Jordan CT, Upchurch D, Szilvassy SJ, Guzman ML, Howard DS, Pettigrew AL, Meyerrose T, Rossi R, Grimes B, Rizzieri DA, et al. The interleukin-3 receptor alpha chain is a unique marker for human acute myelogenous leukemia stem cells. Leukemia. 2000;14(10):1777-84

9. Vergez F, Green AS, Tamburini J, Sarry J-E, Gaillard B, Cornillet-Lefebvre P, Pannetier M, Neyret A, Chapuis N, Ifrah N, et al. High levels of CD34 + CD38low/-CD123+ blasts are predictive of an adverse outcome in acute myeloid leukemia: a Groupe Ouest-Est des Leucémies Aiguës et Maladies du Sang (GOELAMS) study. Haematologica. 2011;96(12):1792-8.

10. Jin L, Lee EM, Ramshaw HS, Busfield SJ, Peoppl AG, Wilkinson L, Guthridge MA, Thomas D, Barry EF, Boyd A. Monoclonal antibody-mediated targeting of CD123, IL-3 receptor a chain, eliminates human acute myeloid leukemic stem cells. Cell Stem Cell. 2009:5(1):31-42.

11. Lyman SD, Jacobsen SE. c-kit ligand and Flt3 ligand: stem/progenitor cell factors with overlapping yet distinct activities. Blood. 1998:91(4):1101-34.

12. Gilliland DG, Griffin JD. The roles of FLT3 in hematopoiesis and leukemia. Blood. 2002;100(5):1532-42.

13. Drexler HG. Expression of FLT3 receptor and response to FLT3 ligand by leukemic cells. Leukemia. 1996;10(4):588-99.

14. Meierhoff G, Dehmel U, Gruss HJ, Rosnet O, Birnbaum D, Quentmeier H, Dirks W, Drexler HG. Expression of FLT3 receptor and FLT3-ligand in human leukemia-lymphoma cell lines. Leukemia. 1995;9(8):1368-72.

15. Al-Mawali A, Gillis D, Lewis I. Characteristics and prognosis of adult acute myeloid leukemia with internal tandem duplication in the FLT3 gene. Oman Med J. 2013;28(6):432-40

16. Nakao M, Yokota S, Iwai T, Kaneko H, Horiike S, Kashima K, Sonoda Y, Fujimoto T, Misawa S. Internal tandem duplication of the flt3 gene found in acute myeloid leukemia. Leukemia. 1996;10(12):1911-8.

17. Kottaridis PD, Gale RE, Frew ME, Harrison G, Langabeer SE, Belton AA, Walker H, Wheatley K, Bowen DT, Burnett AK, et al. The presence of a FLT3 internal tandem duplication in patients with acute myeloid leukemia (AML) adds important prognostic information to cytogenetic risk group and response to the first cycle of chemotherapy: analysis of 854 patients from the United Kingdom Medical Research Council AML 10 and 12 trials. Blood. 2001;98(6):1752-9.

18. Blau O, Berenstein R, Sindram A, Blau IW. Molecular analysis of different FLT3-ITD mutations in acute myeloid leukemia. Leuk Lymphoma. 2013;54(1):145-52.

19. Qiu S, Wang M, Wang J. New insight of leukemic stem cell. Stem Cell and Translational Investigation. 2014;1;e178:1-3.

20. Bennett JM, Catovsky D, Daniel MT, Flandrin G, Galton DA, Gralnick HR, Sultan C. Proposed revised criteria for the classification of acute myeloid leukemia: a report of the French-American-British Cooperative Group. Ann Intern Med. 1985;103(4):620-5.

21. Lacombe F, Durrieu F, Briais A, Dumain P, Belloc F, Bascans E, Reiffers J, Boisseau MR, Bernard P. Flow cytometry CD45 gating for immunophenotyping of acute myeloid leukemia. Leukemia. 1997;11(11):1878-86.

22. Al-Mawali A, Gillis D, Hissaria P, Lewis I. Incidence, sensitivity, and specificity of leukemia-associated phenotypes in acute myeloid leukemia using specific fivecolor multiparameter flow cytometry. Am J Clin Pathol. 2008;129(6):934-45.
23. Murphy KM, Levis M, Hafez MJ, Geiger T, Cooper LC, Smith BD, Small D, Berg KD. Detection of FLT3 internal tandem duplication and D835 mutations by a multiplex polymerase chain reaction and capillary electrophoresis assay. J Mol Diagn. 2003:5(2):96-102.

24. Abu-Duhier FM, Goodeve AC, Wilson GA, Care RS, Peake IR, Reilly JT. Genomic structure of human FLT3: implications for mutational analysis. Br J Haematol. 2001;113(4):1076-7.

25. Munoz L, Nomdedeu JF, Lopez O, Carnicer MJ, Bellido M, Aventin A, Brunet S, Sierra J. Interleukin-3 receptor alpha chain (CD123) is widely expressed in hematologic malignancies. Haematologica. 2001;86(12):1261-9.

26. Sperr WR, Hauswirth AW, Florian S, Ohler L, Geissler K, Valent P. Human leukaemic stem cells: a novel target of therapy. Eur J Clin Invest. 2004;34 Suppl 2:31-40.

27. Al-Mawali A, Gillis D, Lewis I. The use of receiver operating characteristic analysis for detection of minimal residual disease using five-color multiparameter flow cytometry in acute myeloid leukemia identifies patients with high risk of relapse. Cytometry B Clin Cytom. 2009;76B(2):91-101.

28. de Leeuw DC, Denkers F, Olthof MC, Rutten AP, Pouwels W, Schuurhuis GJ, Ossenkoppele GJ, Smit L. Attenuation of microRNA-126 expression that drives CD34+ 38- stem/progenitor cells in acute myeloid leukemia leads to tumor eradication. Cancer Res. 2014;74(7):2094-105.

29. Al-Mawali A, Gillis D, Lewis I. The role of multiparameter flow cytometry for detection of minimal residual disease in acute myeloid leukemia. Am J Clin Pathol. 2009;131(1):16-26.

30. Taussig DC, Pearce DJ, Simpson C, Rohatiner AZ, Lister TA, Kelly G, Luongo $J$, Danet-Desnoyers GA, Bonnet D. Hematopoietic stem cells express multiple myeloid markers: implications for the origin and targeted therapy of acute myeloid leukemia. Blood. 2005;106(13):4086-92.

31. Zhi L, Wang M, Rao Q, Yu F, Mi Y, Wang J. Enrichment of N-Cadherin and Tie2-bearing CD34+/CD38-/CD123+ leukemic stem cells by chemotherapyresistance Cancer Lett. 2010:296(1):65-73.

32. Qiu S, Jia $Y$, Xing $H$, Yu T, Yu J, Yu P, Tang $K$, Tian Z, Wang H, Mi Y. $\mathrm{N}$-Cadherin and Tie2 positive CD34+ CD38-CD123+ leukemic stem cell populations can develop acute myeloid leukemia more effectively in NOD/SCID mice. Leuk Res. 2014:38(5):632-7.

33. Schnittger S, Schoch C, Dugas M, Kern W, Staib P, Wuchter C, Loffler H, Sauerland CM, Serve H, Buchner T, et al. Analysis of FLT3 length mutations in 1003 patients with acute myeloid leukemia: correlation to cytogenetics, FAB subtype, and prognosis in the AMLCG study and usefulness as a marker for the detection of minimal residual disease. Blood. 2002;100(1):59-66.

34. Thiede C, Steudel C, Mohr B, Schaich M, Schakel U, Platzbecker U, Wermke M, Bornhauser M, Ritter M, Neubauer A, et al. Analysis of FLT3-activating mutations in 979 patients with acute myelogenous leukemia: association with FAB subtypes and identification of subgroups with poor prognosis. Blood. 2002;99(12):4326-35.

35. Meshinchi S, Woods WG, Stirewalt DL, Sweetser DA, Buckley JD, Tjoa TK Bernstein ID, Radich JP. Prevalence and prognostic significance of Flt3 internal tandem duplication in pediatric acute myeloid leukemia. Blood. 2001;97(1):89-94.

36. Abu-Duhier FM, Goodeve AC, Wilson GA, Care RS, Peake IR, Reilly JT. Identification of novel FLT-3 Asp835 mutations in adult acute myeloid leukaemia. Br J Haematol. 2001:113(4):983-8.

37. Yoshimoto G, Miyamoto T, Jabbarzadeh-Tabrizi S, lino T, Rocnik JL, Kikushige Y, Mori Y, Shima T, Iwasaki H, Takenaka K. FLT3-ITD up-regulates MCL-1 to promote survival of stem cells in acute myeloid leukemia via FLT3-ITD-specific STAT5 activation. Blood. 2009:114(24):5034-43.

38. Levis M, Murphy KM, Pham R, Kim KT, Stine A, Li L, McNiece I, Smith BD, Small D. Internal tandem duplications of the FLT3 gene are present in leukemia stem cells. Blood. 2005:106(2):673-80.

39. Lumkul R, Gorin NC, Malehorn MT, Hoehn GT, Zheng R, Baldwin B, Small D, Gore S, Smith D, Meltzer PS, et al. Human AML cells in NOD/SCID mice: engraftment potential and gene expression. Leukemia. 2002;16(9):1818-26.

40. Rombouts WJ, Blokland I, Lowenberg B, Ploemacher RE. Biological characteristics and prognosis of adult acute myeloid leukemia with internal tandem duplications in the Flt3 gene. Leukemia. 2000;14(4):675-83.

41. Angelini DF, Ottone T, Guerrera G, Lavorgna S, Cittadini M, Buccisano F, De Bardi M, Gargano F, Maurillo L, Divona M. A leukemia-associated CD34/ CD123/CD25/CD99+ immunophenotype identifies FLT3-mutated clones in acute myeloid leukemia. Clin Cancer Res. 2015:21(17):3977-85.

42. Lin M-T, Tseng L-H, Dudley JC, Riel S, Tsai H, Zheng G, Pratz KW, Levis MJ, Gocke CD. A novel tandem duplication assay to detect minimal residual disease in FLT3/ITD AML. Mol Diagn Ther. 2015;19(6):409-17. 
43. Jan M, Snyder TM, Corces-Zimmerman MR, Vyas P, Weissman IL, Quake SR, Majeti R. Clonal evolution of preleukemic hematopoietic stem cells precedes human acute myeloid leukemia. Sci Transl Med. 2012;4(149): 149ra118. 149ra118.

44. Shih LY, Huang CF, Wu JH, Lin TL, Dunn P, Wang PN, Kuo MC, Lai CL, Hsu HC. Internal tandem duplication of FLT3 in relapsed acute myeloid leukemia: a comparative analysis of bone marrow samples from 108 adult patients at diagnosis and relapse. Blood. 2002;100(7):2387-92.

45. Kottaridis PD, Gale RE, Langabeer SE, Frew ME, Bowen DT, Linch DC. Studies of FLT3 mutations in paired presentation and relapse samples from patients with acute myeloid leukemia: implications for the role of FLT3 mutations in leukemogenesis, minimal residual disease detection, and possible therapy with FLT3 inhibitors. Blood. 2002;100(7):2393-8.

46. Nazha A, Cortes J, Faderl S, Pierce S, Daver N, Kadia T, Borthakur G, Luthra R, Kantarjian H, Ravandi F. Activating mutations of the FMS-like tyrosine kinase-3 internal tandem duplication (FLT3-ITD) at complete response and relapse in patients with acute myeloid leukemia. Haematologica. 2012;97(8):1242-5.

47. Warren M, Luthra R, Yin CC, Ravandi F, Cortes JE, Kantarjian HM, Medeiros $\sqcup$, Zuo Z. Clinical impact of change of FLT3 mutation status in acute myeloid leukemia patients. Mod Pathol. 2012;25(10):1405-12.

48. Cloos J, Goemans B, Hess C, Van Oostveen J, Waisfisz Q, Corthals S, De Lange D, Boeckx N, Hählen K, Reinhardt D. Stability and prognostic influence of FLT3 mutations in paired initial and relapsed AML samples. Leukemia. 2006;20(7):1217-20.

49. Majeti R. Clonal evolution of pre-leukemic hematopoietic stem cells precedes human acute myeloid leukemia. Best Pract Res Clin Haematol. 2014;27(3):229-34.

50. Mizuki M, Schwable J, Steur C, Choudhary C, Agrawal S, Sargin B, Steffen B, Matsumura I, Kanakura Y, Bohmer FD, et al. Suppression of myeloid transcription factors and induction of STAT response genes by AML-specific Flt3 mutations. Blood. 2003;101(8):3164-73.

51. Moretti S, Lanza F, Dabusti M, Tieghi A, Campioni D, Dominici M, Castoldi GL. CD123 (interleukin 3 receptor alpha chain). J Biol Regul Homeost Agents. 2001;15(1):98-100.

52. Al-Mawali A. Leukemic stem cells shows the way for novel target of acute myeloid leukemia therapy. J Stem Cell Res Ther. 2013;3(4):151.

53. Fan $D$, Li Z, Zhang $X$, Yang $Y$, Yuan $X$, Zhang $X$, Yang $M$, Zhang Y, Xiong D. AntiCD3Fv fused to human interleukin-3 deletion variant redirected $T$ cells against human acute myeloid leukemic stem cells. J Hematol Oncol. 2015;8(1):18.

\section{Submit your next manuscript to BioMed Central and we will help you at every step:}

- We accept pre-submission inquiries

- Our selector tool helps you to find the most relevant journal

- We provide round the clock customer support

- Convenient online submission

- Thorough peer review

- Inclusion in PubMed and all major indexing services

- Maximum visibility for your research

Submit your manuscript at www.biomedcentral.com/submit

) Biomed Central 